\title{
Oppineisuuden puolesta
}

\author{
Maria Forsman
}

https://orcid.org/0000-0001-9601-9117

Arvio teoksesta Sari Kivistö \& Sami Pihlström: Sivistyksen puolustus: miksi akateemista elämää tarvitaan? Gaudeamus, 2018. 248 s.

Asiasanat: sivistys; tiedepolitiikka; tieteet (erikoisalat); arvostus; akateemikot

Olen suurten ikäluokkien viimeistä vuosikertaa. Minun sukupolvessani monelle koulutus ja mahdollisuus opiskella ei ollut itsestään selvää. Peruskoulua ei vielä ollut, oppikouluun piti pyrkiä ja lukukausimaksutkin piti maksaa. Suvussani ei ollut akateemisia esikuvia, mutta omat vanhempani näkivät koulunkäynnin mahdollisuutena sosiaaliseen nousuun ja parempaan elämään.

Tästä näkökulmasta kaikenlainen koulutuksen väheksyntä, jota on ilmennyt mm. yliopistojen rahoituksen leikkaamisena ja oppineisuutta vähättelevänä puheena, on tuntunut sivistymättömältä ja tyhmältä. Niinpä yleisen kirjallisuustieteen professori Sari Kivistön ja uskonnonfilosofian professori Sami Pihlströmin kirja "Sivistyksen puolustus" on virkistävää luettavaa. Kirjassa annetaan arvoa humanistis-yhteiskuntatieteelliselle tutkimukselle, suomen kielellä(kin) kirjoittamiselle, akateemiselle elämänmuodolle, kirjastoille, kirjalliselle kulttuurille ja ylipäänsä sivistykselle.

Kirja on kantaa ottava puheenvuoro tähän aikaan, jolloin koulutuksella itsensä maailmankartalle nostaneen kansan poliittiset päättäjät vähättelevät tiedon merkitystä ja hitaasti kypsyvää sivistystä. Aikamme suosii pikakoulutuksia ja nopeaa valmistumista työelämään, jossa kuitenkaan ei kaikille ole töitä tarjolla. Opiskelun ja oppimisen halutaan näkyvän numeroina, vaikka ymmärrystä ja viisautta on vaikea mitata luvuin. Samaan aikaan pyritään tuotteistamaan sellaista, mikä on nähty itsessään arvokkaana. Taidetta arvioidaan sen mukaan, mitä hyötyä siitä on. Kirjallisuuden terapeuttisista ominaisuuksista puhutaan sen sijaan, että nähtäisiin lukeminen nautintona ja kokemuksena. 
Kivistön ja Pihlströmin konkreettiset esimerkit tutkijana olemisesta ja tieteen ulkopuolelta tulevista paineista valaisevat hyvin sitä, mistä nyt on kysymys. Mitä tieteessä oikein tapahtuu? Onko akateemista vapautta enää missään, edes yliopistossa? Joutuvatko tutkijat toimeentulonsa vuoksi toimimaan juuri niin kuin heitä halutaan ohjailla? Ryhtyvätkö he sopeuttamaan tutkimusaiheensa niin, että ne vastaavat jotain Suomen Akatemian tutkimusohjelmaa tai oman laitoksensa strategiaa? Opitaanko tieteellisen ajattelun sijaan taktikoimaan, kilpailemaan ja poimimaan pikavoittoja, jotta perheen toimeentulo olisi turvattu edes seuraavaksi vuodeksi?

No, tällaistahan elämä akateemisessa maailmassa useimmille tieteentekijöille on ollut ennenkin. Parempina aikoina vain pelastusrenkaita on ollut enemmän tarjolla. Nekin tutkijat, jotka toimivat jonkin tutkimuskentän reunalla, saattoivat saada työlleen rahoitusta ja yhteisön tukea. Nyt tutkimukseen ja opetukseen vaikutetaan poliittisilla päätöksillä. Ja kun maan hallituksessa on ministereitä, jotka eivät arvosta koulunkäyntiä tai joilla ei ole minkäänlaista kokemusta akateemisesta maailmasta, seuraukset ovat nähtävissä.

Kivistö ja Pihlström kuuluvat akateemiseen eliittiin. Molemmilla on professuuri ja käsittääkseni siinä asemassa mahdollisuus tehdä haluamaansa tutkimusta. He puolustavat kaltaistensa oikeutta hitaaseen tutkimukseen, ajatteluun ja ajatusten kypsyttämiseen. Heidän ei välttämättä tarvitse sopeutua niihin raameihin, jotka nuorempia tutkijoita ahdistavat tai jotka saavat lahjakkaat nuoret pakenemaan akateemista maailmaa muihin töihin. Kuitenkin he puolustavat myös näitä tulevia tutkijoita ja ovat huolissaan suomalaiseen tieteen tulevaisuudesta.

Olin työelämäni viimeisinä vuosina tutkimuksen arviointiin liittyvissä hankkeissa, joissa mm. bibliometrisin menetelmin arvioitiin tieteen edistymistä. Olin ja olen edelleen huolissani humanistis-yhteiskuntatieteellisen tutkimuksen oikeanlaisesta arvioinnista luonnontieteeseen perustuvan tutkimuksen rinnalla. Tutkimuksen vaikuttavuus ei aina näy juuri nyt, vaan ehkä vuosien tai vuosikymmenten kuluttua. Kaikkea ei voi numeroin ilmaista - tietoa, ymmärrystä, viisautta. Olen ollut huolissani suomen kielen kuihtumisesta tieteen kielenä. Siitä myös Kivistö ja Pihlström ovat huolissaan. Toisaalta he aivan oikein toteavat, että myös humanistisissa tieteissä on aloja ja tutkimusta, joissa kansainvälinen yhteisö ja englannin kielellä kirjoittaminen on luonnollista ja tärkeää. Kielen valintaan vaikuttaa se, keille tutkimustuloksista halutaan kertoa. Kieli on väline tiedon välittämisessä.

Luonnontieteellisen tutkimuskulttuurin ajattelu on hallinnut tutkimuksen arviointia ja rahoituksen suuntaamista. Luonnontieteilijöiden julkaisemisen tavat ja muodot - nopeasti usein ryhmätyönä kirjoitettuja artikkeleita uusista löydöistä kansainvälisiin tiedelehtiin - on tuotu myös niille aloille, joille se ei luontevasti sovellu. Kivistö ja Pihlström kirjoittavat hienosti hitaan yksin kirjoittami- 
sen merkityksestä ja monografian julkaisemisen tarpeellisuudesta. Monografian kirjoittaminen on tutkijalle kiireetön prosessi, ja monografian lukeminen vaatii samoin keskittymistä ja aikaa. He pohtivat lineaarisen kerronnan merkitystä ja sitä, miten digitaalinen julkaiseminen voi sitä muuttaa ja vaikuttaa toisenlaisen lukutavan omaksumiseen. Määritelmänomaisesti he toteavat, että monografiaa voidaan kutsua "intellektuaalisesti ekologiseksi julkaisumuodoksi, jonka kantavia arvoja ovat kiireettömyys, kestävyys ja näkemyksellisyys" (s. 82).

Kirjoittajien mukaan myös tieteestä on tullut markkinoinnin kohde, eikä aina hyvässä mielessä. Tutkijoiden tulisi olla valovoimaisia esiintyjiä, jotka osaavat tuoda raflaavasti esiin omaa tutkimustaan. Toisaalta tutkijoita saatetaan pyytää keskustelemaan televisioon tai radioon niin, että mukana on tieteenvastaista näkemystä edustava ns. kokemusasiantuntija, joka saattaa omakohtaisilla esimerkeillä lytätä asiallisen, ehkä esiintymään tottumattoman tutkijan. Eipä siis ihme, että media käyttää mielellään samoja verbaalisesti lahjakkaita tutkijoita ottamaan kantaa myös sellaisiin kysymyksiin, jotka eivät ole tutkijan omaa aluetta. Hiljainen humanisti, joka on tehnyt arvokasta tutkimusta, mutta joka ei osaa tuotteistaa itseään ja tutkimustaan, jää usein tuntemattomaksi.

Kaiken kaikkiaan asiantuntijuuden kriisi ja sivistysvihamielisyys ovat Kivistön ja Pihlströmin huolenaiheita. He nostavat esiin yliopiston perustehtävien - tutkimuksen ja opetuksen - vahvistamisen ja arvostamisen sekä eliitin roolin. Eliitti-sanaan on sisältynyt negatiivisia merkityksiä ja eliitti on usein nähty kansasta erillään olevana ryhmänä, jota julkisuudessa on oikeus vähätellä. Kirjoittajat esittävät antipopulistisen sivistysprojektin, jossa eliitillä on suuri vastuu. Sivistystä ei voida edistää "kansan ehdoin". "Sivistysprojektia tulee toteuttaa "kansaa" kuunnellen, kaikenlaisia ääniä aidosti ymmärtämään pyrkien [...], mutta sitä voi toteuttaa sivistyneistö itse [...] avarakatseisesti, erilaisia toiseuksia kohdaten, omaa näköalaansa jatkuvasti laajentaen" (s. 39).

Kun työskentelin kirjastoalalla, koin vahvasti olevani osa tiedeyhteisöä. Siksi se, että jouduin eri tilanteissa puolustamaan kirjastoja tutkijoille tai yliopiston hallintoväelle, tuntui välillä absurdilta. Kirjastolle myönnetyt määrärahat ovat tiedeyhteisölle suunnattuja, eivät siltä pois otettuja. Voi ehkä sanoa niin, että kirjastoissa jalostetaan tietoa tutkijoille ja opiskelijoille helpommin käytettävissä olevaan muotoon. Kirjastojen luokitukset, aineiston luettelointi, tietokannat aineiston valinnasta puhumattakaan - asettavat tietoa tarjottimelle. Kas tässä, olkaa hyvä!

Sari Kivistö ja Sami Pihlström kirjoittavat kauniisti kirjastoista. Kirjasta välittyy se, miten tärkeitä kirjastot ovat heille olleet ja miten he ovat kokeneet kirjaston tiloissa jonkinlaista onnen tunnetta. Humanistille ja yhteiskuntatieteilijälle kirjasto on pyhä paikka ja aarreaitta. Kun luonnontieteellisesti ajattelevalle ihmiselle on haluttu perustella kirjaston merkitystä tiedeyhteisössä, on käytetty 
vertausta kirjastosta "humanistin laboratoriona". Kivistö ja Pihlström tuovat kirjastoa esiin paikkana, jossa voi ennakoimattomasti löytää jotain, mitä ei osaa etsiä. He tarkastelevat toisaalta kirjastoa äärettömyytenä, toisaalta taas sitä, miten kirjasto muistuttaa meitä rajallisuudesta ja kuolevaisuudesta, ja toteavat akateemiselle elämänmuodolle ratkaisevan tärkeän monimuotoisuuden olevan niissä molemmissa näkökulmissa olennaista.

Kirjan viimeinen luku käsittelee akateemista ikääntymistä. Nyt minun oli tarkistettava, minkä ikäisiä kirjoittajat ovat, sillä niin kiinnostavasti he tuota kysymystä problematisoivat. Nuoriahan he vielä ovat, alle viidenkymmenen! Tutkijan elämän parhaissa vuosissa! Mutta siitä näkökulmasta nuoren tieteentekijän akateeminen elämä on vielä lähellä ja tulevia vuosia voi nähdä edessään. Kirjoittajat tarkastelevat "sekä historiallisesti että filosofisesti yhtäältä historiallisuuden, perinteen ja vanhuuden sekä toisaalta uutuuden, uudelleen alkamisen ja nuoruuden välistä jännitettä' (s. 203-204). He tuovat tieteen historiasta esimerkkejä sekä ihmelapsista että vanhan tutkijan avoimuudesta uudelle tiedolle. Selvästi he karttavat nuorten ja vanhojen vastakkainasettelua ja toteavat, miten oman työn merkityksen arvioinnin tulee lähteä muiden työn arvostamisesta. "Meistä parhaatkin seisovat jättiläisten hartioilla, ja ne, jotka eivät tätä ymmärrä, putoavat niiltä hartioilta" (s. 214).

Kivistö ja Pihlström tunnustautuvat konservatiiveiksi ja humboldtilaisen sivistysyliopiston arvoperustaan nojautuviksi. He sitoutuvat myös siihen traditioon, jossa pidetään itsearvoisen merkityksellisenä tiedon ja totuuden tavoittelua kriittisen tieteellisen menetelmän avulla. Viime vuosien yliopistouudistuksia he eivät katso hyvällä, vaan ovat huolissaan niiden vaikutuksista akateemiseen elämänmuotoon.

Tämä kirja on kriittinen puheenvuoro nykyistä tiedepolitiikkaa kohtaan. Kritiikin taustalla on vankkaa tietoa, konkreettisia esimerkkejä ja selvää suivaantumista pinnalliseen ja markkinahenkiseen käsitykseen tieteen tekemisestä. Tällaisia kirjoja tarvitaan, jotta ne voisivat toimia maamerkkeinä ja historiantutkimuksen lähteenä, kun Suomen korkeakoulupolitiikkaa arvioidaan vuosikymmenten kuluttua.

Kirjoitan tätä Agricolan ja suomen kielen päivänä huhtikuussa 2018. Olen ylpeä, että voin kirjoittaa suomeksi suomalaiseen tiedelehteen.

Maria Forsman $^{1}$

1 Toim. huom.: VTT Maria Forsman valittiin vuoden tieteentekijäksi 2013. Ks. lisätietoja Tieteetekijöiden liitto, Vuoden tieteentekijä - johtava tietoasiantuntija Maria Forsman, https://tieteentekijoidenliitto.fi/media/tiedotteet/tiedotteet_2013/vuoden_ tieteentekija_-_johtava_tietoasiantuntija_maria_forsman.28.news 